\title{
Comparative Study of Different Carriers Inoculated with Nodule Forming and Free Living Plant Growth Promoting Bacteria Suitable for Sustainable Agriculture
}

\author{
Naveen Kumar Arora', Saskhi Tiwari' and Ratan Singh ${ }^{1 *}$ \\ Department of Environmental Microbiology, Baba Saheb Bhim Rao Ambedkar University Vidya Vihar Rai Barely Road, Lucknow, India
}

\begin{abstract}
Rhizobium and pseudomonas are bacteria that's are able to increase plant growth and provide nutrients to them in any condition even in stress condition and also have different plant growth characteristics such solubilized the minerals, fix the nitrogen and also chelate the inorganic compound for example iron and make it utilizable to plants thus making it beneficial as microbial bio fertilizer and known it plant growth promoting rhizobacteria. The aim of this study was to determine potential five different carrier material for survival of PGPR (Rhizobium and pseudomonas strain) isolated from Trigonella foenum Graecum at room temperature for 8 weeks. Samples from the carrier materials (Sterilized and Non- sterilized) were taken every week and tested for the survivability and sustainability of the two different PGPR in it by determining viable cell count $\left(\mathrm{CFUg}^{-1}\right)$. The result showed that after eight weeks of storage treatment of carrier Coriander husk, saw dust and Begasse stored at room temperature $\left(25-28^{\circ} \mathrm{C}\right)$ was able to sustain the highest viable cell number of $\mathrm{Co}$ inoculation of Rhizobia and Pseudomonas followed by individual. These two carrier also had acceptable changes in $\mathrm{pH}$ value and moisture content followed by wood ashes and sand.
\end{abstract}

Keywords: Suitable carriers; Formulation; Nodule Forming Bacteria; Free Living Bacteria; sustainable agriculture

\section{Introduction}

Rhizobium and Pseudomonas both species are suitable known bacteria to be used as potential microbial inoculants or biofertilizer and biopesticides [1].The microbial inoculants peculiarly those of rhizobacteria interact with both plant root and soil thus provide favorable effect on the plant growth and this was termed as plant growth promoting rhizobacteria (PGPR) [2-4]. The use of microbial inoculants as a biofertilizer increase crop yield, environment-friendly and can be utilized as an alternative or to reduce the usage of inorganic nitrogen fertilizer [5 -6], however inoculation of microbes, normally those of the selected bacterial inoculants have a very short shelf life due to getting improper way of nutrition continuously in nature. The biological activity of the PGPR may decline rapidly if the handling and storage is not done in the discipline way. The application of selected carrier materials for the bacterial inoculants proves to be beneficial to protect the bacteria and have long been practiced [7]. There are different materials of carrier are used now a days in agriculture, such as Karnolite, Peat, Charcoal etc. but mostly these are high cost and difficult to find also find environmentally unfriendly.

Among various types of carrier materials, the usage of begasse, Saw dust, and wood ashes as the microbial inoculants carrier has also been demonstrated and considered most frequently utilized carrier. The reason behind it these were able to support high number of PGPR and maintained its survivability due to high moisture holding capacity and large surface area, low of cost and environmental ecofriendly. The usage of Saw dust and begasse as a carrier was also preferred because of its high water retention capability due to their flashy structure. Therefore it became easy to support bacterial growth and happen to be less desirable as a carrier.

The success of microbial inoculation to promote growth of plant is vastly influenced by the number of introduced into the soil [8]. Therefore it is important to find out the duration of the bacterial survivability in the respective carrier materials to ensure the desired level of bacterial population remains viable for the inoculants to sustain efficient. Simultaneously the selected carrier materials must also have the properties such as cost effective, dissolve well in water so that bacteria can be released and able to tolerate harsh environmental conditions [9]. Thus the objective of the present work was comparative study of suitability, sustainability, viability of four different carriers at room temperature.

\section{Material and Methods}

\section{PGPR inoculants preparation}

Two selected species of rhizobacteria Rhizobium RH24 and Fluorescent Pseudomonas PF23 isolated from Rhizosphere of Fenugreek (Trigonella foenum-graecum) plants cultivated at the residence area of SGPGI MS Lucknow [4]. The criteria of bacterial screening were their mineral solubilization, biocontrol, plant growth promotion and antibiosis [10-12]. The cultures of Rhizobium and Pseudomonas were maintained on slants of YEMA (Yeast extract mannitol agar) and Kings'B medium respectively at $4^{\circ} \mathrm{C}$.

\section{Prepared inoculants Formulations}

The bacterial inoculants were prepared in following four formulations in three different manners (Pseudomonas, Rhizobium and Consortium): 1) Saw Dust, 2) Wood Ashes, 3) Sand,4) Begasse,5) Coriander husk.

*Corresponding author: Ratan Singh, Department of Environmenta Microbiology, Baba Saheb Bhim Rao Ambedkar University Vidya Vihar Rai Barely Road, Lucknow, India, Tel: 7405498542; E-mail: ratansingh458@gmail.com, rattumicro729@gmail.com

Received: March 01, 2014; Accepted May 19, 2014; Published May 31, 2014

Citation: Arora NK, Tiwari S, Singh R (2014) Comparative Study of Different Carriers Inoculated with Nodule Forming and Free Living Plant Growth Promoting Bacteria Suitable for Sustainable Agriculture. J Plant Pathol Microb 5: 229. doi:10.4172/2157-7471.1000229

Copyright: (C) 2014 Arora NK, et al. This is an open-access article distributed under the terms of the Creative Commons Attribution License, which permits unrestricted use, distribution, and reproduction in any medium, provided the original author and source are credited. 


\begin{tabular}{|c|c|c|c|}
\hline S.No. & Carrier materials & $\begin{array}{c}\text { Quantity of carriers } \\
\text { (in gm) }\end{array}$ & $\begin{array}{c}\text { Water Absorbed } \\
\text { (in ml) }\end{array}$ \\
\hline 1 & Sand & 10 & 9.10 \\
\hline 2 & Begasse & 10 & 42 \\
\hline 3 & Saw dust & 10 & 70 \\
\hline 4 & Wood Ashes & 10 & 30 \\
\hline 5 & Coriander Husk & 10 & 75.10 \\
\hline
\end{tabular}

Table 1: Water Holding Capacity of Different Selected Carrier Materials.

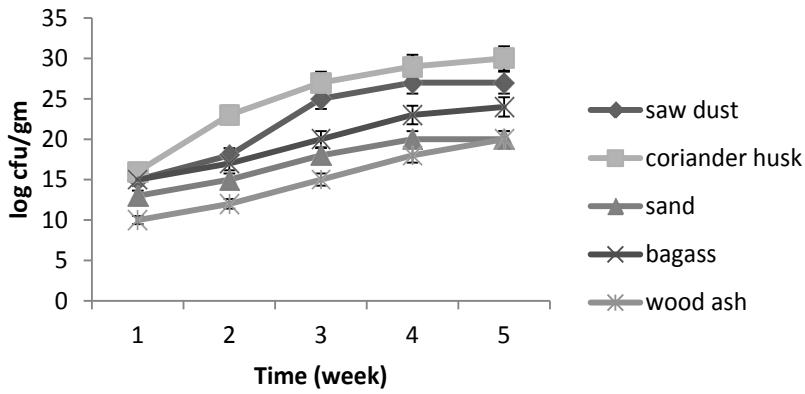

Figure 1: Population density (cfu g-1) of co inoculation in different sterilized carriers Weekly showing survivality of bacteria up to 5 weeks in carrier materials.

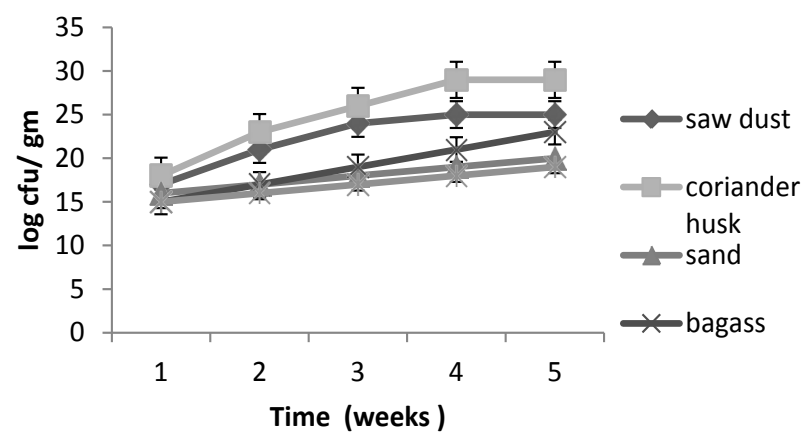

Figure 2: Population density (cfu g-1) of RH24 in different sterilized carriers Weekly showing survivality of bacteria up to 5 weeks in carrier materials

Formulation were prepared in two different set up first is in under sterilized conditions in a laminar flow hood second one is in unsterilized condition. All there selected formulation materials were autoclaved separately. The bacterial strains were cultured in King's B medium (Pseudomonas), Yeast Extract Mannitol broth (Rhizobium), Minimal Salt medium (Consortium) at $28^{\circ} \mathrm{C}$ for $24-48$ hrs.

\section{Experimental Conditions}

$10 \mathrm{gm}$ of the carrier materials were taken into small disposable glasses. The disposable glasses are inflexible. It was mixed well in the glasses, each glass of sterilized carrier materials was then inoculated with Rhizobium and Pseudomonas and consortium of both bacteria in triplicate $\left(>10^{8}\right.$ cells $\left.\mathrm{mL}^{-1}\right)$. Bacterial Suspension was aseptically mixed with Carrier according to their water holding capacity (checked by adding water in 10 gram of carriers). The treatments involved in the experiments were as follows:

Sand (Control), Sand+RH24 inoculums, Sand+PF 23 inoculums, Sand+Consortium inoculums, Saw dust (control), Saw dust $+\mathrm{RH}$ 24 inoculums, Saw Dust+PF23 inoculums, Saw Dust+Consortium inoculums, Begasse (Control), Begasse+Rhizobia inoculums,
Begasse $+\mathrm{PF} 23$ inoculums, Begasse + Consortium inoculums, Wood ashes (Control), Wood Ashes+Rhizobia inoculums, Wood Ashes+Pseudomonas inoculums, Wood Ashes Consortium inoculums, Coriander husk (Control), Coriander husk+Rhizobia inoculums, Coriander husk+Pseudomonas inoculums, Coriander husk+Consortium inoculums. For each treatment, three replicates were prepared in small polyethylene bags. Each glass contained $10 \mathrm{~g}$ of the carrier materials. The selected carrier materials were tasted per week for 5 weeks properly for viable cell count $\left(\mathrm{CFU} \mathrm{g}^{1}\right)$.

\section{Total viable cell count of inoculated PGPR in formulation-}

1 gram sample from each glass was putted into test tubes add and $9 \mathrm{ml}$ of sterile distilled water hen mixed thoroughly to ensure complete separation of the bacteria from the carrier. Until $10^{-10}$ serial dilution was performed. Two drops of $10 \mu \mathrm{L}$ from each dilution was spreaded on Minimal salt agar with two replicates for each dilution [13] all the plate was incubated at $28 \pm 2^{\circ} \mathrm{C}$ for $24 \mathrm{~h}$ before the colony formed was counted and the $\mathrm{cfu} \mathrm{g}^{-1}$ was determined.

\section{Analysis of water retention time of carriers}

Carriers were taken $1 \mathrm{gm}$ in weighted petriplates and take weight of carriers immediate and kept it in hot air oven at $105^{\circ} \mathrm{C}$ for $24 \mathrm{hrs}$ and take dry weight (gravimetric method for moisture content) with glass petriplates and analyzed the moisture content using formulation. This method repeated for in triplicate for each carrier.

\section{Results}

\section{Water Holding Capacity of Selected Carrier Materials}

Water holding capacity of all selected carriers was different [14]. Table 1 show the water absorbs by coriander husk was high followed by saw dust and Begasse. Water retention time was high of coriander husk having near about 9 days followed by saw dust having near about one week and begasse having 2-4 days to hold water. Water holding capacity of carrier prove that the carrier have capacity to have much level of bacteria in it till the good time period showing capability of carriers.

\section{Growth of PF23 and RH24 in selected carriers}

The response of bacterial inoculation under different formulations varied with different treated formulation used. The inoculation resulted in significant increase in most of the growth parameters with respect to control. There are reports of plant growth promotion ability of both the bacteria [4] used in this study. The bacterial populations that were recorded initially lower in the case of Saw dust formulation with Consortium, increased with time (Figure 1) followed by RH24 (Figure 2) and PF 23 (Figure 3). In contrast to this, the maximum number of bacteria in the case of Coriander husk and Saw dust formulation with Consortium was recovered after 3 week of inoculation declined after 5 week in case both bacteria (PF 23 and RH 24) .

\section{Viable cell count of PGPR in carrier materials}

In Figure 4 for storage room temperature, carrier material Coriander husk have high water holding capacity was the best amongst all three types of treatment of Saw dust and Begasse performed well with consortium followed by Wood Ashes and sand after 4 week where the difference became apparent. Only treatment of Coriander husk to maintains optimum viable cell count which was higher than $10^{-7} \mathrm{CFU} \mathrm{g} \mathrm{g}^{-1}$. The reduction in number of bacteria over time was lesser for coriander husk compared to other carrier materials tested. All treatments performed better under the temperature of $28^{\circ} \mathrm{C} \pm 30^{\circ} \mathrm{C}$. 


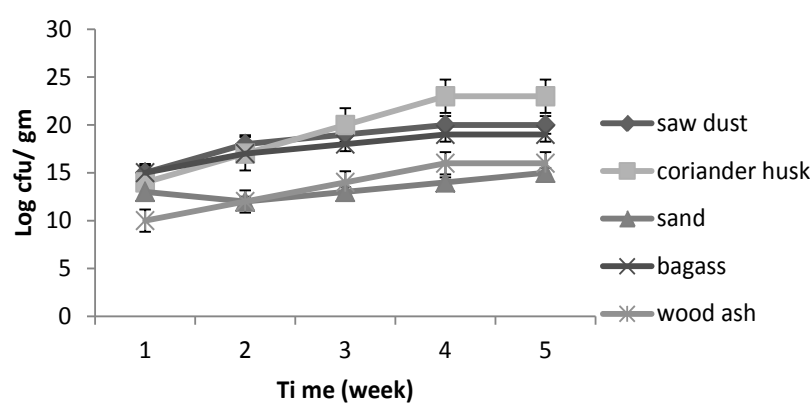

Figure 3: Population density (cfu g-1) of PF23 in different sterilized carriers Weekly showing survivality of bacteria up to 5 weeks in carrier materials.

\begin{tabular}{|c|c|c|c|c|c|}
\hline \multicolumn{5}{|c|}{ Water Retention Capacity (\%) } & \\
\hline Retention Time & Coriander husk & Saw dust & Begass & Wood ashes & Sand \\
\hline 1 & $7.20 \%$ & $6.50 \%$ & $6.08 \%$ & $5.74 \%$ & $3.01 \%$ \\
\hline 2 & $6.80 \%$ & $6.44 \%$ & $6.21 \%$ & $4.21 \%$ & $3 \%$ \\
\hline 3 & $6 \%$ & $5.52 \%$ & $5.03 \%$ & $4.00 \%$ & $2.01 \%$ \\
\hline 4 & $5.99 \%$ & $5.41 \%$ & $4.33 \%$ & $3.51 \%$ & $1.09 \%$ \\
\hline 5 & $5.30 \%$ & $4.32 \%$ & $4.01 \%$ & $3.00 \%$ & $1.01 \%$ \\
\hline
\end{tabular}

Table 2: Water Retention capacity (\%) per retention time period.

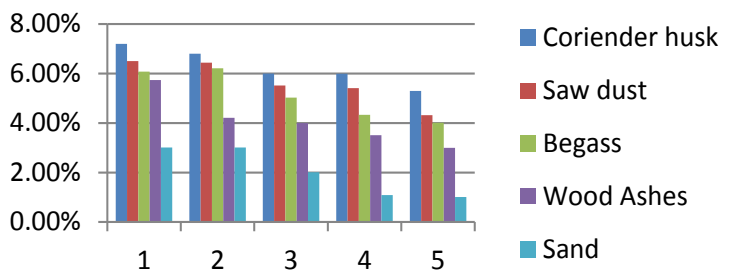

Figure 4: Retention Time and water retention capacity of different carriers

\section{Water retention time of carriers}

The water retention time of each carrier materials using the appropriate method showing in Table 2 the result shows that coriander husk have high retention capacity for water $7.2 \%, 6.8 \%, 6 \%, 5.99 \%, 5.3 \%$ for $1^{\text {st }} 2^{\text {nd }}, 3^{\text {rd }} 4^{\text {th }}, 5^{\text {th }}$,week respectively followed by saw dust $6.5 \%, 6.44 \%$, $5.32 \%, 5.41 \%, 4.32 \%$ per gm for $1^{\text {st }} 2^{\text {nd }}, 3^{\text {rd }} 4^{\text {th }}, 5^{\text {th }}$ week respectively. (Table 2, Figure 4)

\section{Discussion}

The effects of carrier material and storage temperature on the viable cell number of the biofertilizer are important because the overall functioning and reliability of the biofertilizer to increase crop yield may be affected by it. Selection of the proper type of carrier material is also most crucial issue, and also it must be capable to support to have a good amount of bacterial inoculants for as long as possible. Over the storage time of five weeks, the viable cell count of all carrier materials tested showed a decline for room temperature. The material Coriander husk showed the best result with highest viable cell count for normal temperature. In the meantime former intervention with different selected carrier materials only the treatment of begasse and saw dust showed acceptable viable cell count in normal temperature $\left(\sim 28^{\circ} \mathrm{C}\right)$.

The choice of the carrier materials used for the production of biofertilizer is also important as the chemical and physical characteristics of the materials differed from each other. Using type of selected carrier materials may cause impact the viability of both PGPRs bacteria inoculated in it. It must suit and become able to maintain eminent number of bacteria and also as many types of strains as possible [15] In conclusion the objective of the study which was to find the best carrier for microbial inoculants of locally isolated RH24 and PF23 were accomplished successfully with Coriander husk being a more superior carrier material as compared to Saw dust and begasse. Temperature also plays an important role in the survival of the PGPR that was inoculated into the carrier materials. There were difference in the self-life and efficacy of the bacteria for each formulation. Formulation of PF23 and RH24 either individually or as consortium stored at $28^{\circ} \mathrm{Croom}$ temperature showed better shelf life and increases in $\mathrm{CFU} \mathrm{g}{ }^{-1}$. The storage temperature of $28^{\circ} \mathrm{C}$ was the best suited for this PGPRs. Coriander husk material remains the best to be used in biofertilizer.

\section{Acknowledgement}

The Work was affirmed by Department of Environmental microbiology BBAU Vidya Vihar Raibareli Road Lucknow to provide lab facility and support for completing this research work. Authors acknowledge to their Supervisor Dr Naveen Kumar Arora and his PhD Scholar Ms. Sakshi Tiwari for proper guidance every time and also to their colleagues Shatrohan Lal, Vijay Kant Dixit and Amar Jyoti Das for their motivation and help during research work.

\section{References}

1. Otieno PE, Muthomi JW, Cheminingwa GN , Nderitu JH (2009) Effect of rhizobia inoculation farm yard manure and nitrogen fertilizer on nodulation and yield of food. grain legume J Biol Sci 9: 326-332.

2. Glick BR (2003) Phytoremediation: synergistic use of plants and bacteria to clean up the environment. Biotechnol Adv 21: 383-393.

3. Verma JP, Yadav J, Tiwari KN, Lavakush, Singh V (2010) Impact of plant growth promoting rhizobacteria on crop production. J Agric Res 5: 954-983.

4. Singh R, Arora NK, Gautam P, Lal S (2013) Enhancement of plant growth of Trigonella foenum-graecum by Coinculation of fluorescent Pseudomonas and Rhizobium for the sustainability of agriculture Asian J of Plant Sci and Res 3 : 74-79.

5. Woyessa D, Assefa A (2011) Effect of plant growth promoting rhizobacteria on growth and yield of Tef (Eragrostis tef Zucc. Trotter) under greenhouse condition. Res J Microbiol 6: 343-355.

6. Yasmin F, Othman R, Sijam K, Saad MS (2007) Effect of PGPR inoculation on growth and yield of sweet potato. J Boil Sci 7: 421-424.

7. Ardakani SS, Hedari A, Tayebi L, Mohammadi M (2010) Promotion of cotton seedlings growth characteristics by development and use of new Bioformulations, Int, J botany 6: 95-100

8. Duquenne P, Chenu C, Richard G, Catroux G (1999) Effect of carbon source supply and its location on competition between inoculated and established bacterial strains in sterile soil microcosm. FEMS Microbiol Ecol 29: 331-339.

9. FAO (1993) Technical Handbook on Symbiotic Nitrogen Fixation Food and Agricultural 179. Organization of the United Nations Rome Pages: 162.

10. Pandey A, Sharma E \& Palni LMS (1998) Influence of bacterial inoculation on maize in upland farming systems of the Sikkim Himalaya Soil Biology and Biochemistry 30: 379-384.

11. Pandey A, Palni LMS \& Bag N (2000) Biological hardening of tissue culture raised tea plants Biotechnology Letters 22: 1087-1091.

12. Pandey A, Palni LMS, Mulkalwar P, Nadeem M (2002) Effect of temperature on solubilization of tricalcium phosphate by Pseudomonas corrugate Journal of Scientific and Industrial Research 61:457-460.

13. Hoben HJ1, Somasegaran P (1982) Comparison of the Pour, Spread, and Drop Plate Methods for Enumeration of Rhizobium spp. in Inoculants Made from Presterilized Peat. Appl Environ Microbiol 44: 1246-1247.

14. Viji R, Prasanna P. Rajesh (2012) Assessment of Water Holding Capacity of Major Soil Series of Lalgudi, Trichy India. Journal of Environmental Research And Development 7: 393-398.

15. Bashan $Y$ (1998) Inoculants of plant growth-promoting bacteria for use in agriculture Biotechnology Advances 16: 729-770. 